\title{
PHILOSOPHY AND DISAGREEMENT
}

BRIAN RIBEIRO

Department of Philosophy and Religion

University of Tennessee at Chattanooga

brianribeiro@hotmail.com

SUMMARY: Disagreement as we find it in both the history and the contemporary practice of philosophy is an inadequately understood phenomenon. In this paper I outline and motivate the problem of disagreement, arguing that "hard cases" of disagreement confront us with an unresolved, and seemingly unresolvable, challenge to the rationality of philosophical discourse, thereby raising the specter of a worrisome form of metaphilosophical skepticism. A variety of responses and attempted evasions are considered, though none are found to be particularly satisfying: Thus, the specter remains unexorcised.

KEY WORDS: disagreement, consensus, skepticism, relativism, metaphilosophy

RESUMEN: El desacuerdo que encontramos tanto en la historia como en la práctica contemporánea de la filosofía es un fenómeno mal entendido. En este trabajo hago un esbozo y aduzco los motivos del problema del desacuerdo, argumentando que los "casos difíciles" de desacuerdo nos confrontan con un problema sin resolver y al parecer sin posibilidad de resolverse, que pone en duda la racionalidad del discurso filosófico, y con lo cual surge el espectro de una preocupante forma de escepticismo metafilosófico. Examino varias respuestas y tentativas de evasiones, aunque ninguna de ellas es particularmente satisfactoria. Así, el espectro sigue sin ser exorcizado.

PALABRAS CLAVE: desacuerdo, consenso, escepticismo, relativismo, metafilosofía

Philosophy is not only rife with disagreement; one might even say that philosophy is in the business of disagreement. That's who we are, or what we do, qua philosophers: we question, dispute, object, oppose, beg to differ, quibble, and sometimes even cavil. Since this is so, one might expect that philosophy would, long ago, have worked out a fairly sophisticated account of disagreement —of its nature, origin(s), and its implications for the practice of philosophy - but it seems fairly clear to me that this is not so.

I find that very surprising. After all, one of the other things which philosophy is in the business of is being a thoroughly and uncompromisingly self-critical enterprise, i.e. being an enterprise that not only thinks about its paradigmatic objects of inquiry but also thinks about itself and its relation to its own inquiries. Thus, one might be surprised to find that philosophy is in the business of doing (at least) two things (viz., disputing and being relentlessly 
self-critical), but doesn't appear to be in the business of doing them in conjunction (being relentlessly self-critical about this disputing). ${ }^{1}$

Ask yourself then: Why is there all this disagreement? My project here is to outline an account of the kind of disagreement most relevant to philosophy and to offer a selective history of the problem of disagreement in philosophy, thereby articulating the range of responses available to us as philosophers in addressing this problem. As we will see, the account I develop raises some very serious worries about the stability or legitimacy of our ordinary proceedings as philosophers. I will argue that disagreement in philosophy poses a powerful and as yet unresolved challenge to philosophy or its practitioners or both. Or, to put this in other words, that pending an adequate response to the challenge of disagreement in philosophy a powerful form of skepticism seems quite near and quite threatening. ${ }^{2}$

I want to emphasize that my main aim in this paper is to make the urgency of the problem itself manifest. I will, in addition, be considering a range of possible solutions to the problem, drawn from the (limited) history of this debate, and I will try to make clear why

${ }^{1}$ The problem of disagreement, while little discussed by philosophers in relation to philosophy (pace Sextus and Hegel), is often discussed by philosophers in relation to other non-philosophical areas. For example, the problem of religious diversity is a standard topic in the philosophy of religion, where it generates the pluralism/exclusivism debates. See, for example, the collection of papers in Quinn and Meeker 2000, especially the pieces by Craig and Hick. The topic is included in nearly every philosophy of religion textbook as well. See Pojman 2003, Martin and Bernard 2003, Shatz 2002, and Peterson et al. 2001, each of which devotes a section to it. It is likewise the problem of persistent disagreement in the political arena that has helped to provoke recent literature on value pluralism, deliberative democracy, political contestation, and so on. See Rawls 1993, Nagel 1987, Larmore 1987, Hampshire 2000, Gutmann and Thompson 1996, Fish 1999, Galston 2002, and Sunstein 2003. Yet somehow philosophers have failed to notice the obvious fact that philosophers disagree as much as if not more than religious believers and democratic citizens. I want to explore the problem of disagreement in philosophy. Interestingly, there are, very recently (within only the last five years), some signs of an awakening amongst epistemologists about the problem of disagreement, though generally this new work is not focused on the metaphilosophical issues which are my concern here. See Feldman 2006, Kelly 2006, Christensen 2007, Elga 2007, and the papers collected in Feldman and Warfield 2010.

${ }^{2}$ My theme - disagreement - was embraced by the ancient skeptics as one of their standard weapons. On the skeptical "mode" of disagreement, see Sextus Empiricus 2000 (1.164-165), and Diogenes Laertius 1925 (2: 9.88). To see the mode of disagreement in action, see Sextus Empiricus 2000 (2.37-38, 2.110-112, 3.3-5, 3.3032, 3.56, 3.136-138, 3.180-182, and 3.239). Nonetheless, many good philosophers have underestimated the force of this kind of skeptical argument. For the some under-appreciative remarks about this form of skeptical argument, see, for example, Hume 2000b (12.21) and Hegel 1995 (p. 350). 
those solutions seem inadequate to me. If they really are inadequate, then we are left with an undogmatic but powerful form of metaphilosophical skepticism. Seeing no defensible alternatives, I confess that I am tempted to embrace this form of skepticism, to accept it as a kind of skeptical solution of the problem of disagreement. But I expect to make few converts. I should however at least like to see readers convinced that some solution is needed and that philosophy cannot legitimately continue to all but ignore the problem of disagreement that it generates.

\section{Wittgenstein's Hard Cases}

Before attempting to offer any account of disagreement, I want to try to limit the field a bit. My topic is not disagreement simpliciter, but rather a certain kind of disagreement, the individual instances of which I will call hard cases. ${ }^{3}$ In order to prepare the way for appreciating the difficulties posed by these hard cases, it will be instructive to consider some more easily resolvable cases of disagreement.

CASE \#1. Suppose my girlfriend and I have a disagreement over the temperature on a steamy day in mid-July. She maintains that it must be 110 degrees out there, while I deny this, claiming that it is 95 degrees. Suppose I am right (and I know it) because I just checked the thermometer outside on our deck. If I inform her of this, then - leaving aside certain possibilities - ${ }^{4}$ she will change her mind and end our dispute. Indeed, there was nothing much afoot in this case: I had a bit of information she didn't have. Her opinion was not unreasonable, and if I had lacked support for mine, she might reasonably have continued in her belief that it was 110 . But whether I had the necessary support to end the dispute or not, it is quite plain that the dispute's resolution hung largely on the availability of some bit of local information.

CASE \#2. Suppose I get into a dispute with my nephew about the causes of locomotion in living animals. He maintains - not unreasonably for his age - that animals move by means of spirituous fluids ("go-juice" he calls it) that animate their limbs. This I deny. But when it comes to resolving the dispute, I have a hard time convincing him he's wrong. Showing him this would involve calling on all sorts of things from biology, things he won't know for years yet, and

${ }^{3}$ I will offer an explicit account of what a "hard case" is in section 4 . To, as it were, tease out the essence of a "hard case" of disagreement is one of my aims.

${ }^{4}$ I will ignore for present purposes the possibility that my girlfriend suspects my honesty, or my ability to accurately read a thermometer, etc. 
which he therefore does not regard as having probative force against his view. His ignorance is more widespread than that we considered in CASE \#l. Still, I might tell him, "I understand what you mean, but one day you will see things as I do. You have a lot left to learn about the world". 5

CASE \#3. Suppose I get into a dispute with a student in a formal logic course over whether a particular claim can be proven given certain premises and the rules of inference and substitution we have discussed in class. He denies this. I try to explain the proof, taking it step by step, but he always seems to get bogged down. I begin to suspect that the problem is that he doesn't know the rules well enough, so I drill him on these rules for an hour. But suppose I discover that he knows the rules quite well. It's just that when the proofs get too long (let's say forty steps or more), he gets stuck and can't solve proofs of that sort. I might (eventually, hesitantly) come to believe that this student just can't grasp proofs of that sort.

Disagreements such as those in these three cases can be resolved, at least in the minimal sense that their origin can be understood, fairly simply. Disagreements of this sort commonly involve either a local lack of information (local ignorance: CASE \#1), a more widespread lack of information (widespread ignorance: CASE \#2), or a lack of ability (lack of (one kind of) intelligence: CASE \#3). ${ }^{6}$ I have made myself the "victor" in each of the three cases to illustrate an important theme common to the cases: In each case, I conclude that I am better placed than my interlocutor and this better placement explains our disagreement. For instance, I have just read the thermometer (\#1), or I have had training in biology (\#2), or I have the ability to see the structure of long, involved proofs and to hold this

${ }^{5}$ Or if I found it inappropriate to say this to him, I might think it and say something more gentle instead.

${ }^{6}$ Due to issues of complexity, I will only be considering these three factors in the main body of the text. However, in addition to the three factors cited, there is also a large class of what we might call idiosyncratic psychological determinants (IPDs). Some cases of disagreement are probably best understood as arising from IPDs. For example, whether a person is (characteristically) confident or insecure, gregarious or solitary, thrill-seeking or risk-aversive, etc., can affect that person's judgments. In this light, we might think of Nietzsche's genealogical method as explaining disagreements by citing the causally-determining IPDs, and citing IPDs as explanatory could lead one to a form of relativism. For an accessible and interesting recent treatment of Nietzschean genealogy emphasizing relativistic incommensurability, see MacIntyre 1990 (chapter 2). For an alternative reading, see Nehamas 1998 (chapter 5), especially pp. $146 \mathrm{ff}$. Unfortunately, IPDs introduce complications I do not wish to address in the main text, so my few comments on them will be reserved for the footnotes. 
in mind while working on the proof over a long period of time (\#3). In each case, I will think we disagree because you are less ideally suited to judge than I am. Moreover, were this disability removed, presumably you would change your mind and end the dispute by coming to accept the right opinion (my opinion). So, resolving such disputes (in the minimal sense of coming to adequately understand them) involves my attributing some type of cognitive liability or limitation to my interlocutor.

Now in light of these cases, I want to consider a case Wittgenstein presents in On Certainty. ${ }^{7}$ I wish to argue that Wittgenstein's case has certain generalizable features and that these features locate a kind of disagreement, the instances of which are hard cases as I use that term. The content of Wittgenstein's case is familiar enough. He is thinking of the disagreement between a traditional Christian believer and some irreligious objector. These two have a disagreement - "Is the world the result of divine fiat or not?" - but how shall we resolve it? Here is what Wittgenstein says: "Very intelligent and welleducated people believe in the story of creation in the Bible, while others hold it as proven false, and the grounds of the latter are well known to the former" $(O C \S 336)$.

The implicit color of the passage suggests that the reader will be one of the latter, and hence the point is made by "defending" the former, but nothing hangs on this aspect of the case - the idea, I suppose, is that (by the twentieth century at least) the burden is with the Christian to show that she is not laboring under some sort of cognitive liability. Wittgenstein's claim is that she need not be. Such a Christian might be "very intelligent", "well-educated", and aware of what will be said against her views. That is, she needn't be unintelligent, ignorant in some widespread way (uneducated) or ignorant in some local way (unaware of the counterarguments).

According to Wittgenstein such people exist. I (B.R.) disagree with them about the origin of the world. But what can I say here? Wittgenstein says such people need not be stupid or uneducated and it need not be true that they are unaware of standard atheological arguments. If Wittgenstein is right, then how can I explain our disagreement? To say that they have not adequately understood the counterarguments or that they are not able to see the full force of them or that they are ignoring some basic fact(s) about the world is

${ }^{7}$ Hereafter cited as $O C$. All citations are to section numbers. 
to renege on the earlier concession ${ }^{8}$ and to insist that all traditional Christians must be either unintelligent or ignorant (either locally or in some more widespread way). So, again, what can I say?

\section{Wittgenstein's Solution to the Hard Cases}

The passage which I quoted from Wittgenstein $(O C \S 336)$ was his answer to one of the omnipresent rhetorical questions with which his later work is filled. His question was "But is there no objective character here?"9 The passage I quoted suggests that Wittgenstein's answer is "No". ${ }^{10}$ Later in On Certainty, he returns to discussing hard cases of disagreement and we find him saying that "[w]here two principles really do meet which cannot be reconciled with one another, then each man declares the other a fool and heretic" (§ 611). In such cases we enter into "combat" (\$\$ 609, 610, 612) with our interlocutor. Wittgenstein asks, "[B]ut wouldn’t I give him reasons?" and answers, "Certainly; but how far do they go? At the end of reasons comes persuasion. (Think what happens when missionaries convert natives.)" (§ 612).

I don't have the space here to provide a full account of Wittgenstein's epistemological views in On Certainty, but at least this much seems clear to me. In On Certainty, hard cases of disagreement (i.e., cases which Wittgenstein believes cannot be resolved by attributing some sort of cognitive liability) are resolved by embracing the suggestion that in such cases there is always some sort of fundamental dispute behind the scenes. These disputes are the products of our accepting different "rules", since it is these "rules" which give shape to our practices $(\S \S 95,136,167,308)$. However, since these "rules" cannot (on the $O C$ account) ${ }^{11}$ be justified or discredited, grounded or ungrounded ( $\S 162,358-359)$, true or false (§205), "reconciliation"

${ }^{8}$ Namely the concession that Christians with none of these liabilities exist. To insist that any Christian must have some such liability is to rule out the possibility of a cognitively un-disabled Christian.

${ }^{9} O C \S 336$. The full passage reads as follows: "But what men consider reasonable or unreasonable alters. At certain periods men find reasonable what at other periods they found unreasonable. And vice versa. But is there no objective character here? Very intelligent and well-educated people believe in the story of creation in the Bible, while others hold it as proven false, and the grounds of the latter are well known to the former."

${ }^{10}$ Very much the same rhetorical question is raised earlier in $O C$ and answered much more explicitly, and the answer is relativistic (see $\S 108$ ). So my suggestion that Wittgenstein's indirect response at $\S 336$ means "No" is not surmise only.

${ }^{11}$ One can also find this view expressed in Wittgenstein 1953, where the standard meter bar in Paris is used to illustrate the point: Whether something is a meter long 
in hard cases always requires conversion ( $\S 612$, and also $\S 92$ ). If reconciliation is to occur, then one of us must forsake reason-giving, (non-rationally) reject our old rule, and (non-rationally) accept a new rule, thereby ending the dispute. ${ }^{12}$

Now, I personally have grave doubts about the adequacy of this account of the hard cases. The suggestion that every hard case bottoms out in something which is, in some sense, ultimate strikes me as strained and promissory at best, but I don't propose to dispute Wittgenstein's solution for present purposes. Let's just grant that some sort of relativistic explanation of hard cases is possible. ${ }^{13}$

Is a relativistic solution also necessary, or are there any other possibilities? Well, one way we might avoid the relativistic solution is by insisting that even in hard cases there must be a cognitive liability of some sort, either in my interlocutor or in me. But in genuinely hard cases the liability (or liabilities) might be virtually impossible to detect with any reasonable degree of assurance, and this difficulty might produce a corresponding disinclination to engage in attributions of liability. In other words, we can avoid the relativistic view by embracing a skeptical view - someone is flawed but we cannot reasonably or confidently say who. Furthermore, this connection between relativism and skepticism is not merely an accident of this specific case, as it has long been recognized that the same considerations about disagreement can be invoked for either relativistic or skeptical purposes.

can be determined by comparing it to the standard meter bar, but one cannot check the standard meter bar in the same way (by holding it up to itself, as it were). Thus, moves in a game may be justified by calling upon the rules of the game, but there is nothing to justify the rules themselves. The standard meter bar neither $i s$, nor is not, a meter long; it is the rule for determining what a "meter" is. See $1953, \S 50$.

12 The dialectic here calls to mind Richard Rorty's remark about disputes involving our "final vocabularies": "[I]f doubt is cast on the worth of these words", we are left with "no noncircular argumentative recourse [...]. [B] eyond them there is only helpless passivity or a resort to force" (1989, p. 73). As long as "force" can involve both physical force and non-rational persuasive force (Wittgenstein's "conversion"), I take Rorty's view to be the same as Wittgenstein's on this point. See also Fogelin 1985.

${ }^{13}$ As noted above (note 6), if we were to extend our discussion to cover cases involving IPDs, we could arrive at a form of Nietzschean relativism where judgments are relative to particular patterns of IPDs. Thus, for example, certain judgments might be seen as appropriate from a "slave" perspective (one constellation of IPDs), whereas those same judgments will appear ridiculous from a "master" perspective (a different constellation of IPDs). Thus, introducing IPDs could lead us to see two different forms of relativism as possible: Wittgensteinian rule-relativism and Nietzschean perspectivism. 


\section{Relativism and Skepticism}

Since the connection between relativism and skepticism plays an important role in my overall argument, I want to pause to discuss it. In many cases the very same evidence can be put forward to support either a relativistic or a skeptical conclusion. Take an ancient example from Sextus Empiricus's Outlines of Pyrrhonism. There is a great deal of disagreement over things "good, bad and indifferent" (2000, 3.168). Sextus tells us that both philosophers and ordinary people dispute over the appropriateness of - among other things - sodomy, having intercourse with a woman in public, prostitution, tattooing, men wearing earrings, men wearing dresses, marrying your mother or sister, incest, masturbation, eating human flesh, adultery, polygamy, cutting the throats of everyone over sixty years old, infanticide, piracy, stealing, cowardice, and so on (3.199-218). Now perhaps some of these disputes will seem less compelling to you than they seemed to Sextus, but we could easily enlarge his list to include disputes over the permissibility of drinking to excess, using illegal drugs, using birth control, abortion, human cloning, prenatal gene therapy, stem cell research, eating the flesh of nonhuman animals, state-sanctioned executions, euthanasia, pornography, gay marriage, terrorism, pacifism, and so forth.

What should we make of such disagreements? On the one hand, we might infer that each group (or, more radically, each individual) has an idiosyncratic set of standards, and therefore the apparently conflicting claims are not really in conflict. Nothing is good, bad, or indifferent simpliciter, but only in relation to some frame of reference and there is no universal frame of reference. ${ }^{14}$

Or, on the other hand, we might maintain that there is an objective good, an objective bad, and an objective indifferent, and then insist that when intelligent and well-informed people disagree about the good, the bad, and the indifferent, this raises insoluble epistemic problems. Thus we are driven to skepticism.

We might, of course, try to maintain our dogmatic views in the face of disagreement by attributing cognitive limitations to our opponents. ${ }^{15}$ But in many cases, any attribution of liability is just as

${ }^{14}$ As indicated by previous notes (notes 6 and 13), we could interpret these "frames of reference" as consisting of sets of rules (Wittgenstein) or constellations of IPDs (Nietzsche).

${ }^{15}$ Wittgenstein alludes to such name-calling as we should expect to find in such cases $(O C \S 611)$, remarking that "[o]f course there are all sorts of slogans which will be used to support our proceedings" $(O C \S 610)$ Think of the role of calling other 
reasonably directed at us as at our opponents. In those cases - the hard cases - we appear to be faced with relativism or skepticism.

\section{Philosophy: A Cornucopia of Hard Cases}

Philosophy is full of hard cases of disagreement. Sure, we have all been on the losing end of a conversation about when Descartes' Meditations were first published (or in which language they were), or about how the Greek term eudaimonia is normally translated, or about whether Hegel did or did not attend divinity school before pursuing philosophy, and so forth. But most of our disagreements are not of this sort. Most of the disagreements we have - and certainly most of the disagreements we spend time and ink arguing aboutmeet the following hard cases conditions:

$H C C_{1}$ I believe that the person I am disputing with is either as intelligent as me OR more intelligent than me OR, minimally, that she is bright enough so that lack of intelligence is not the explanation for our disagreement

$H C C_{2}$ I believe that the person I am disputing with is either as welleducated as I am OR more so OR, minimally, that it is not her being "uneducated" that explains our disagreement

$H C C_{3}$ I believe that the person I am disputing with is well-aware of the standard objections to her position, has thought about the implications of her position for other areas of philosophy, has spent time preparing and polishing responses to various challenges: briefly, she's thought it through, and thoroughly - thoroughly enough so that our disagreement is not be explained on the basis of her having simply overlooked something

I believe that more often than not in philosophical disputes each of these three conditions $\left(H C C_{1}-H C C_{3}\right)$ is satisfied.

Consider an illustrative case. Why do my colleague So-\&-So and I have such markedly different epistemological positions? Is he stupid? Or perhaps poorly trained? Or perhaps he just hasn't heard that argument of mine that would surely change his mind? But, wait, I

groups/people "primitive", "backward", or "superstitious", or of calling our own proceedings "modern", "advanced", "enlightened", "progressive", or "scientific", backed by (as we will say) — think about the role of this expression — "cold, hard facts". 
shared that argument with him three months ago. And I know he was well-trained. And he's certainly not stupid or unable to grasp abstruse epistemological matters. So what do I say? What do I think? I think I am right and he is wrong. But, much to my chagrin, I cannot find any cognitive liability which he seems to have. Indeed, even supposing that cognitive liability $i s$ the explanation of our disagreement, I have no evidence at all - discounting my Moorean bravado, of course - that the liability is his, not mine.

And suppose Wittgenstein was right. Suppose there is no liability at work at all, only a difference in the "rules" we play by. That "solution" when brought to bear on disagreement in philosophy raises more problems than I have time to track, ${ }^{16}$ but here's the biggest: If every hard case requires a difference in the "rules" embraced by the disputants, then given the extent of hard case disagreement in philosophy we have a very relative relativism on our hands! Since conversion on such a scale seems completely unlikely, any reasongiving at all might seem like wasted breath. ${ }^{17}$

I think that most disagreements in philosophy really are hard cases $=d e f$. cases where attributions of cognitive liability seem either (i) out and out wrong (so, like Wittgenstein, we go relativist) or (ii) hopelessly beset by epistemic problems (so, like the Pyrrhonists, we go skeptical): we either play by different "rules" or else we play by the same "rules", yet one of us incessantly and irremediably goes astray. ${ }^{18}$ Insofar as it is not at all clear that the error rests with my opponent, on what grounds can I continue to reasonably maintain my confidence in my own philosophical positions? Or, then again, on the supposition that my philosophical positions are only reasonable relative to some more or less arbitrary set of "rules" - these might be

${ }^{16}$ These problems would all result from the sort of cross-practice insulationism which Wittgensteinian relativism produces. Were we to self-consciously accept the relativistic solution we would be led to an ever-increasingly narrow tribalism, in which philosophy would grow more and more splintered into factions which —on the Wittgensteinian account- could not hope to rationally adjudicate their disputes. Conversion would be the only hope, and one not to be taken seriously. Wittgenstein's solution would displace most of our philosophical discourse, leaving me to tidy up the details of the views I already share with those of my "tribe". Our exchanges with other tribes, if they did not end altogether, would be reduced to coining clever derogatory epithets with which to label our antagonists (see note 15 above).

${ }^{17}$ Rorty's quip — see note 12 above - seems very apropos here.

${ }^{18}$ Both the hard case conditions $\left(H C C_{1}-H C C_{3}\right)$ and my definition of "hard case" could be modified to include cases involving IPDs, though the complications introduced prohibit me from doing so herein. I leave this as an exercise for the reader. 
called prejudices or biases - I can hardly have the same satisfaction in my views.

If I cannot reasonably attribute some liability to Professor So-\&-So (and thereby explain our disagreement) I appear to be left with relativism or skepticism, neither of which entitles me to see my opinion, or our disagreement, as I previously did. For my own part, I think that our philosophical disputes — many of them anywayare real disputes, and if I thought that the relativistic solution were an appropriate response to disagreement in philosophy, I think I would give up philosophy (not in anger, but in disinterest). But if these disputes are real, how can I carry on? For if the disputes are real, then some cognitive liability is to blame. But the history of philosophy does not look - to me, at least - like the history of uncovering such liabilities.

Take any of my philosophical views, and I find myself surrounded by antagonists, living and dead: Shall I suppose myself to know better? Shall I think I know things they don't? I am sharper, more perceptive; I see things which they miss. I think we should all blush to think such thoughts, but if you do not think them how will you explain the disagreement?

\section{Consensus-Producing Solutions: Hume and Peirce}

We can view both relativism and skepticism as positions that embrace disagreement as a fact, and then make certain concessions to accommodate it. It might naturally occur to us that this is not the only way to go. We might instead view the current state of disagreement as an unhappy circumstance to be rectified rather than wallowed in. That is, we might take an optimistic view of disagreement, seeing it as either in principle or in practice eliminable. Thus, in order to resolve this state of disagreement, we might try to outline a method, or a set of methods, by which consensus could be achieved.

There are certainly many philosophical programmes that have this basic shape. To illustrate the approach and to try to understand its limitations, I will take two examples. ${ }^{19}$ First, consider Hume's

${ }^{19}$ Almost every new method-based philosophical programme is at least implicitly (and often explicitly) committed to this consensus-producing ideal. For example, early in the twentieth century as modern logic was making headway by leaps and bounds, one could find all sorts of philosophers who were inclined to suppose that at last philosophical problems would be (dis)solved by the application of the new logical apparatus. Consider, for example, the Preface to Wittgenstein 1922. When the new logic failed to solve all of philosophy's problems, we next got ordinary language 
theories in ethics and aesthetics. ${ }^{20}$ One train of thought running through Hume's understanding of these matters goes as follows. People's judgments of approbation and disapprobation (whether ethical or aesthetic) are frequently found to conflict. But this state of affairs is in principle and in practice eliminable (to a large extent at least). For example, although aesthetic judgments often conflict (1965, p. 3), there is (Hume thinks) a programme of aesthetic education which, when properly undertaken by a set of inquirers, will produce considerable (if not completely universal) uniformity of judgment. This programme involves several elements (1965, pp. 10-16), ${ }^{21}$ but perhaps its most central feature is the demand that we abstract away the particularities of our own perspective and try to achieve a sort of departicularized, disinterested state. ${ }^{22}$ Hume believes that, were we all in this state, then (for the most part anyway) ${ }^{23}$ we would find ourselves in agreement. The intuition here is that there is something in all of us, ${ }^{24}$ which when properly allowed to operate reveals our deep common nature. If only various forms of distortion or interference were removed, our common sentiments would be manifest, mitigating if not eliminating the problem of evaluative disagreement.

Peirce takes a similar approach. In his famous essay on the "Fixation of Belief" he argues that many methods of belief-formation (including that espoused by philosophers - the so-called a priori method $)^{25}$ will lead to the persistence of disagreement. Peirce argues that of the four methods of belief-formation which he considers, three of these - the method of tenacity, the method of authority, and the $a$

philosophy, making the same sorts of claims. Consider, for example, J.L. Austin's righteous bravado in his 1962, pp. 1-5. Ordinary language philosophy likewise failed to solve all our problems.

${ }^{20}$ For Hume's ethics (in the form that concerns me here) see his Treatise, Book 3. The passages which are of most concern to me are these: 3.1.2.4, 3.3.1.14-18, and 3.3.3.2. For his aesthetics, the central text is "Of the Standard of Taste" (1965).

${ }^{21}$ A listing of the elements is given at Hume, 1965, p. 17.

${ }^{22}$ A similar procedure is applied to ethical judgment in the Treatise. See the passages indicated in note 20 .

${ }^{23}$ Hume allows that some sources of disagreement are ineliminable (1965, $19 \mathrm{ff}$.). But Hume thinks significant consensus would be possible if his programme were consistently adhered to.

${ }^{24}$ For example, "[T] he principles of taste [are] universal, and nearly, if not entirely, the same in all men" (1965, p. 17). "The general principles of taste are uniform in human nature" (1965, p. 19). For a similar comment from the Treatise, see 3.2 .8 , n. 80 .

${ }^{25}$ For the a priori method see Peirce 1986, pp. 252-253. The a priori method proceeds by looking to see what seems "agreeable to reason" in the sense that we are "inclined to believe" it (p. 252). 
priori method - will end in disputes which will unsettle my beliefs. ${ }^{26}$ Since, according to Peirce, "the sole object of inquiry is the settlement of opinion", (1986, p. 248), any method of belief-formation subject to such destabilizing disputes is less than fully satisfactory. If we want to find stable beliefs, ones not subject to the irritation of dispute and disagreement, we must use the right method, the method of science (1986, pp. $253 \mathrm{ff}$.). The method of science promises (according to Peirce) to lead to a stable, rational consensus of opinion - something no other method of belief-formation can offer. If the method of science is followed, "the ultimate conclusion of every man shall be the same" (1986, p. 254).

Although I think I understand the motivations behind consensusdriven approaches like those of Hume and Peirce, I have three objections to such views, which taken together strike me as being decisive. To begin with, the recommended procedures have not produced any considerable degree of consensus in philosophy, nor do they even seem to have significantly increased the degree of consensus in philosophy. In fact, they seem to have had little recognizable effect at all, as far as I can tell. Neither the procedures Hume recommends nor those Peirce recommends have actually produced substantial consensus of any sort in philosophy. Of course, were this the only objection to such views, one might think the appropriate response would be to redouble our efforts at reform. But there are more worries to come.

And the next worry is that such method-based solutions make the resolution of disagreement an entirely epistemological problem. And that approach — while entirely natural, and maybe even unavoidable given certain plausible suppositions - seems inherently doomed. For epistemology is no more settled than any other area of philosophy, and so the very methods for resolving disagreement recommended by Hume and Peirce are themselves the subject of (very vigorous) dispute. Yet we cannot hope to resolve our disagreements by invoking one disputed thing to resolve questions about other disputed things. ${ }^{27}$ Of course, we might say that although the disagreements can't be resolved in a strong sense (by achieving consensus), they

${ }^{26}$ Peirce (1986) argues for the unsettling of tenacity-based belief at p. 250, the unsettling of authority-based belief at pp. 251-252, and the unsettling of a prioribased belief at p. 253 .

${ }^{27}$ Whether this would amount to a formal begging of the question or not is not completely clear. However, it would amount to fallaciously using "premises no more certain than the conclusion", as some logic books put it. This ("premises no more certain than the conclusion") is the genus of which begging the question is one species. 
might be resolved in the weaker sense of being adequately understood. We might say, for example, "Thank you, Peirce! Now we know why philosophers continue to disagree: They refuse to adopt the method of science!" But our confidence in the legitimacy of this resolution will be both unstable and pointless. Unstable, because we may find it hard to be confident this diagnosis is correct; pointless, because this diagnosis doesn't offer any indication of which philosophical opinions (if any) are correct.

Finally, even if such methods could produce consensus, consensus is not in itself sufficient to ensure the rationality of a discourse, without further qualifications being made. Take Hume's aesthetics again. Disagreement in judgments of taste leads Hume to formulate a "standard of taste", that being "a rule by which the various sentiments of men may be reconciled" or, if these cannot be reconciled, at least there will be "a decision [...] confirming one sentiment and condemning another" (1965, p. 5). But the programme of aesthetic education that Hume proposes, even if it could produce consensus for those who follow it, would be no better - if consensus alone is the criterion of success - than any other programme which produced a different set of agreed-upon judgments in its followers. To put the point intuitively, there are many ways of producing consensus, many of which will hardly count as rational or truth-directed - fascist regimes, drugs in the water supply, and so on. And it is hard to see what independent support could be offered, agreeable to all parties, that one method is correct other than the fact that it produces consensus. But many methods can produce consensus, so the (first-order) disagreement in judgments is kicked up one level and becomes a (second-order) disagreement about methods - and then, given present concerns, we're right back where we started. If disagreement in first-order judgments requires a criterion or standard, then disagreements about standards will requires metastandards, and so on. ${ }^{28}$

\section{Finding the Principle at Issue}

At this point I want to try to explicitly formulate the principle which is the backdrop for the argument I've been running. It must be a principle indicating the proper relation between consensus (= nondisagreement) and the rationality of a discourse. I'll start with two

\footnotetext{
${ }^{28}$ For a more detailed version of the argument in this paragraph applied to Hume's consensus-seeking approach to resolving evaluative disagreements, see Ribeiro 2007.
} 
bad versions of the principle and build up to a better one. Start with a principle we can call $\mathrm{R}$ :

(R) If a discourse is rational, then that discourse generates consensus.

But consensus is not a requirement of rational discourse. Some disputes are perfectly compatible with the robust rationality of the discourse in which those disputes take place. Disputes can have many causes, and some disputes will occur in any discourse, however rational it may be. So $(\mathrm{R})$ is false. Consider, then, a second possible principle, $\mathrm{C}$ (which is the logical converse of $(\mathrm{R})$ ):

(C) If a discourse generates consensus, then that discourse is rational.

Unfortunately for C, however, while consensus is not necessary for rational discourse, neither is consensus sufficient for rational discourse, without further qualifications being made. Consensus can have many causes and some of these are clearly inconsistent with the rationality of the discourse which embeds the consensus. If some political tyrant produces consensus by drugging the municipal water supply, or if some religious group produces consensus by appealing to the deep-seated fears of the congregants, or if English professors produce consensus about the great works of English literature by lording it over their impressionable students, then the consensus achieved by such strategies clearly does not entail the rationality of these discourses. So $(\mathrm{C})$ is false as it stands. Finally, let's consider UR:

(UR) If a discourse is unproblematically rational, then that discourse will not generate long-term, widespread, inexplicable and/or irremediable disagreement

Intuitively speaking, if there is enough disagreement over a long enough period for which we cannot determine the cause(s) and/or we have no prospect of removing the cause(s) of such disagreement, then the rationality of that discourse is problematized.

UR seems pretty much correct to me. It places reasonable - even generous - limitations on the kinds of disagreements that should be viewed as problematic, and it also correctly identifies the absence of such disagreements as a necessary (but not sufficient) condition for the (unproblematic) rationality of a discourse. Furthermore, it only 
insists that disagreements of the relevant kind problematize - but do not definitively disprove - the rationality of the discourse which embeds them. Nonetheless, this principle, while limited in all these ways, and so really fairly weak, is still sufficient to undergird all of the worries about the rationality of philosophical discourse which I have presented. ${ }^{29}$ Given any of the views considered so far in this paper, the unproblematic rationality of philosophical discourse seems undercut.

\section{The Historical/Evolutionary Solution: Hegel}

If we are to avoid relativistic or skeptical conclusions about the practice of philosophy or our own participation in that practice, we need either (1) some way of resolving hard cases of disagreement (à la Hume and Peirce) or - here's the new twist- (2) some way of seeing philosophical disagreement as not involving genuine inconsistency or contradiction. Hopefully the arguments I have made so far make (1) look less than promising. Indeed, I have a strong suspicion that (l) can't be done, and I also have a strong suspicion that many philosophers will agree. After all, do you believe —or do you even know someone who believes - that one day philosophers will resolve their disputes, and come to a rational consensus of opinion?

I want now to consider a more radical type of solution: Hegel's historical or evolutionary solution. I want to try to say (in a rough, and definitely incomplete, way) what Hegel's solution is and why it can seem so attractive, and then I will consider whether his solution is satisfactory (or whether it is merely attractive).

First, the solution: In the "Introduction" to his Lectures on the History of Philosophy Hegel takes up the problem posed by the diversity of philosophical opinions (1995, vol. 1, pp. 10-19). He later returns to this theme in its rightful place, namely in his discussion of Pyrrhonian skepticism (1995, vol. 2, pp. 328-373). There, Hegel argues that the apparent contradictoriness of philosophical opinions is in an important sense illusory. He even insists that those who would regard this diversity of opinions as grounds for skepticism are "the timid shrinking from knowledge [...] [trying to make] the inertness of their reason to be a virtue" (1995, vol. 2, p. 350). Hegel argues that the skeptics have settled for a myopic, ahistorical understanding of the diversity. And this myopic, ahistorical perspective leads them

${ }^{29}$ In fact, the principle I've suggested here is very moderate. Stronger principles might be defended, but for rhetorical reasons I've opted for a version that is just strong enough to undergird an interesting form of metaphilosophical skepticism. 
straight to the conclusion that the diversity is necessarily an inconsistency. Hegel argues that though the diversity cannot be denied (1995, vol. 1, p. 17; vol. 2, p. 350), the apparent contradictoriness of philosophical opinions is dissolved when we reject myopic, onesided partiality and come to see all earlier philosophical positions as earlier stages of development (1995, vol. 2, pp. 350-351, 358) headed toward the complete, fully-formed (Hegelian) view. Hegel says that,

The true difference [between the various philosophies] is not a substantial one, but a difference in the different stages of development; and if the difference implies a one-sided view, as it does with the Stoics, Epicureans, and Sceptics, in their totality undoubtedly we first reach truth. (1995, vol. 2, p. 358)

Hegel tells us that if we fall prey to this one-sided myopia, then we will not be able to "comprehend the diversity of philosophical systems as the progressive unfolding of the truth"; instead all we will see are "simple disagreements" (1977, p. 2). But unfolding diversity is not logical inconsistency. Hegel offers us an image:

The bud disappears in the bursting-forth of the blossom, and one might say that the former is refuted by the latter; similarly, when the fruit appears, the blossom is shown up in its turn as a false manifestation of the plant, and the fruit now emerges as the truth of it instead. These forms are not just distinguished from one another; they also supplant one another as mutually incompatible. Yet at the same time their fluid nature makes them moments of an organic unity in which they not only do not conflict, but in which each is as necessary as the other; and this mutual necessity alone constitutes the life of the whole. (1977, p. 2)

Applying this image to the problem at hand, we find Hegel saying that,

$[\mathrm{H}] \mathrm{e}$ who rejects a philosophical system [that is, some new philosopher with his new system] does not usually comprehend what he is doing in this way; and he who grasps the contradiction between them does not, as a general rule, know how to free it from its one-sidedness $[\ldots]$. (1977, p. 2)

Considered historically, the diversity of opinion is best understood, Hegel is saying, as the manifestation of the long, slow struggle away 
from one-sidedness, and emphasis on difference, toward Truth. Understood in this way, we stand to Plato not as two men stand to each other, but rather as a man stands to a boy. The boy is different from, but not in any harmful sense in conflict with, the man he will one day become. We have to view this as, in Hegel's words, "genuine process" (1995, vol. 2, p. 351).

I think the nature of this solution will make its attractiveness quite evident. If philosophical problems can only receive a satisfactory solution in, as it were, the fullness of time, if philosophical solutions have to be built up from the ground up one piece at a time, then when I come along and apply myself to these problems, I may well feel that finally the way has been paved for the right answer. And even if I don't accept an individual version of Hegel's solution (viz. that philosophy has been waiting for me), I may accept a more socially-extended version of that solution. I may believe that philosophy as currently practiced has a better claim to truth than the philosophy of ancient Greece or medieval England or seventeenthcentury France. If philosophy has not been waiting for me, perhaps it has nonetheless been waiting for us.

When one gives the "march of philosophical progress" speech at the end of an introductory course, one often appeals to the labors of philosophical posterity. Through the toil of our predecessors, the road has been paved for us. Though hundreds and even thousands of years of distinction-drawing, conceptual experimentation, and gradual clarification and elucidation, we have been placed - temporally, socially, in a word historically - in a position to do what they could not: to get things right. I think this optimistic view of philosophy's maturation is not only a very appealing perspective, but one which most philosophers implicitly adopt. My last concern will be whether this perspective, once brought to full self-consciousness, can hope to stand as reflectively acceptable.

I think that for many of us Hegel's solution can be hard to embrace in a truly self-conscious way. At least I find myself hardpressed to retain any stable confidence in the hope it offers. After all, while Hegel's solution appears well-suited for explaining some diachronic disagreements (e.g. my disagreement with Plato), it seems less apt for explaining synchronic cases (e.g. my disagreement with my colleague Professor So-\&-So). I might try to accuse Professor So-\&-So of being, as it were, stuck in an earlier stage of development. But he may just as happily turn this criticism around on me.

Moreover, the problems do not end even if such synchronic disagreements can be handled, for the diachronic cases can also revisit 
us. Suppose, for example, that in one hundred years our successors have different views from those we now hold. Won't our successors think the same thoughts about us that we now think about our predecessors? (And, while we're on the subject, didn't our predecessors think these thoughts one hundred years ago about their predecessors? We think our predecessors were wrong, but we aren't - which really shows you the importance of being born exactly when you were! A hundred years sooner and truth would have eluded you!)

Or to take up another worry, I am uncertain that I have any stable confidence in philosophy's having any more or less definite tendency to hone in on truth. I am less certain than I would like to be that the Rational has slowly revealed itself —one leg at a time, seductively - through the years. Were I to express an opinion about where philosophy is going, I would have to say that philosophy seems always headed toward greater and greater fragmentation. We have found issues to disagree over that Plato couldn't have even imagined. Every year new possibilities for dispute are suggested to us. We seem to be headed, not toward any agreement, but toward ever-greater variety in disagreement. ${ }^{30}$

So our situation seems to be this: disagreement in philosophy demands an answer from us. If we are not to embrace relativism or skepticism, and if consensus-producing programmes are both unlikely to work and misdirected, we may find ourselves under enormous pressure to find Hegel's solution acceptable. Indeed, Hegel's solution in one form or another seems to be something we all adopted long ago (if only implicitly), when we were philosophical naifs. But can that solution stand fast in the face of the objections to it? And if not, where are we left?

\section{Concluding Remarks}

I have argued that the apparent ineliminability of disagreements in philosophy problematizes the rationality of philosophical discourse. I find my way to this conclusion neither willingly nor happily, and indeed I would be most pleased to be shown the error of my reasoning, if indeed this may be shown without raising the specter of the very problem at hand.

${ }^{30}$ William James also noted this fragmenting tendency: Our "divergences of conception [ . . s seem] rather to have deepened than to have [been] effaced [... ]" (1967, p. 490). Interestingly, James cites our one-sidedness (how we "emphasize different parts of [objective nature]") as the cause of the fragmentation (1967, p. 490). 
Ah, but there's the rub, you might say. Doesn't my argument have an unfortunately self-referential way of imploding? I say disagreement problematizes philosophy. Okay. But am I not aware that when philosophers are presented with the argument I've given (about philosophy), they will disagree over its cogency, some (perhaps) being persuaded, while others are not? And if disagreement problematizes philosophy, then doesn't disagreement also problematize my (philosophical) argument about philosophy?

This kind of self-refutation worry is old, of course. The Pyrrhonists were presented with versions of it by their dogmatic opponents and they offered a number of replies to it. ${ }^{31}$ And I would certainly agree that some kinds of self-reference are problematic. But here, in this case, I confess that I find this kind of response entirely facile. And this is so not because I think my reflections are in some sense metaphilosophical and therefore not afflicted by the first-order worries about philosophy that I've sketched.

Consider that in one sense the fact that philosophers will disagree over the cogency of my argument actually tends to confirm my argument. I say that philosophers disagree endlessly, and the other philosophers respond by disagreeing with me about that. Or perhaps they can't disagree about whether we disagree - I mean, come on, we do. ${ }^{32}$ Perhaps, instead, they disagree with me about whether our disagreements generate the skeptical consequences I've suggested. Fine, if so, let's discuss my argument in detail. But I refuse to be impressed by a general, blanket charge of self-refutation, as if merely noting the aspect of self-reference relieved philosophers of the burden of addressing the problem(s) I've indicated. Consider what Popkin says in his entry on "Skepticism" for the Encyclopedia of Philosophy. A skeptical argument is best understood as,

an anonymous letter received by a dogmatic philosopher who ... hold[s] a position. The letter raises fundamental problems for the [dogmatic] recipient by questioning whether he had adequate grounds for his assertions and assumptions or whether his system is free from contradictions

${ }^{31}$ For some examples of the dogmatists' self-refutation indictment against Sextus and a sampling of Sextus's replies, see Outlines of Pyrrhonism 2.185-192, and Adversus Mathematicos 8.463-481.

${ }^{32}$ This fact (about philosophical disagreement) has been made especially clear by the findings of the recent PhilPapers Survey (carried out in November 2009). According to their website, "[t]he Survey was taken by 3226 respondents, including 1803 philosophy faculty members and/or PhDs and 829 philosophy graduate students". Rampant disagreement is clearly evidenced in the results. For more details, see $<$ http://philpapers.org/surveys $>$. 
or absurdities. The recipient may try to fend off the attack by challenging whether any philosopher could write the letter without opening himself to similar attacks. By imputing an author, the dogmatist may show the problem involved in consistently stating skepticism, but he does not thereby reply to the arguments in the letter. (1967, vol. 7, p. 459; my emphasis.)

So if you want to view me as guilty of some form of self-stultifying irrationality, be my guest. I say disagreement (of a certain kind) problematizes philosophy, and then I trot out a philosophical argument subject to the same kind of disagreement and suggest that it should persuade. There's certainly some kind of tension in doing that. Maybe I thereby "open myself to similar attacks". (Though, really, what do you want me to do?) But that doesn't mean I'm wrong (= that my metaphilosophically skeptical conclusion is false) and it doesn't really help you one bit. Show me my faulty premise(s). Show me my fallacious inference(s). "Reply to the arguments in the letter." On the upside, I will be happy to thank you for doing so, since I don't like my conclusion any more than I expect (most of) my readers will. ${ }^{33}$

\section{REFERENCES}

Austin, J.L., 1962, Sense and Sensibilia, Oxford University Press, New York.

Christensen, David, 2007, "Epistemology of Disagreement: the Good News", Philosophical Review, vol. 116, no. 2, pp. 187-217.

Diogenes Laertius, 1925, Lives of Eminent Philosophers, vol. 2, trans. R.D. Hicks, Harvard University Press, Cambridge (Loeb Classical Library).

Elga, Adam, 2007, "Reflection and Disagreement", Noûs, vol. 41, no. 3, pp. 478-502.

Feldman, Richard, 2006, "Epistemological Puzzles about Disagreement", in Hetherington 2006, pp. 216-236.

Feldman, Richard and Ted Warfield (eds.), 2010, Disagreement, Oxford University Press, New York.

Fish, Stanley, 1999, "Mutual Respect as a Device of Exclusion", in Macedo 1999, pp. 88-102.

${ }^{33}$ For helpful comments on or discussions about ancestral versions of this paper or its main ideas I would like to thank Scott Aikin, Caleb Clanton, Allen Coates, Rob Talisse, and Derek Turner, as well as audiences at West Virginia University (in 2002), the University of Tennessee at Chattanooga (in 2004), and the Boston 2004 meeting of the Society for Skeptical Studies. 
Fogelin, Robert, 1985, "The Logic of Deep Disagreements", Informal Logic, vol. 7 , no. 1, pp. 1-8.

Galston, William, 2002, Liberal Pluralism, Cambridge University Press, Cambridge.

Gutmann, Amy and Dennis Thompson, 1996, Democracy and Disagreement, Belknap Press, Cambridge, Mass.

Hampshire, Stuart, 2000, Justice Is Conflict, Princeton University Press, Princeton.

Hegel, G.W.F., 1995, Lectures on the History of Philosophy, trans. E.S. Haldane and Frances H. Simson, University of Nebraska Press, Lincoln, 2 vols.

, 1977, Phenomenology of Spirit, trans. A.V. Miller, Oxford University Press, New York.

Hetherington, Stephen (ed.), 2006, Epistemology Futures, Oxford University Press, New York.

Hume, David, , 2000a, A Treatise of Human Nature, ed. David Fate Norton and Mary J. Norton, Oxford University Press, Oxford.

— 2000b, An Enquiry Concerning Human Understanding, ed. Tom L. Beauchamp, Clarendon Press, Oxford.

- 1965, "Of the Standard of Taste", in John Lenz (ed.), Of the Standard of Taste and Other Essays, Bobbs-Merrill, Indianapolis, pp. 324.

James, William, 1967, "The Types of Philosophic Thinking", in John J. McDermott (ed.), The Writings of William James: A Comprehensive Edition, Random House, New York, pp. 482-496.

Kelly, Thomas, 2006, "The Epistemic Significance of Disagreement", in John Hawthorne and Tamar Gendler Szabo (eds.), Oxford Studies in Epistemology, vol. 1, Oxford University Press, New York, pp. 167-196.

Larmore, Charles, 1987, Patterns of Moral Complexity, Cambridge University Press, Cambridge.

Macedo, Stephen (ed.), 1999, Deliberative Politics, Oxford University Press, New York.

MacIntyre, Alasdair, 1990, Three Rival Theories of Moral Enquiry, University of Notre Dame Press, Notre Dame.

Martin, Raymond and Christopher Bernard (eds.), 2003, God Matters: Readings in the Philosophy of Religion, Longman, New York.

Nagel, Thomas, 1987, "Moral Conflict and Political Legitimacy", Philosophy and Public Affairs, vol. 16, no. 3, pp. 215-240.

Nehamas, Alexander, 1998, The Art of Living, University of California Press, Berkeley.

Peirce, Charles, 1986, "The Fixation of Belief", in Writings of Charles $S$. Peirce, vol. 3, Indiana University Press, Bloomington, pp. 242-257.

Peterson, Michael, William Hasker, Bruce Reichenbach and David Basinger (eds.), 2001, Philosophy of Religion: Selected Readings, 2nd ed., Oxford University Press, New York. 
Pojman, Louis (ed.), 2003, Philosophy of Religion: An Anthology, 4th ed., Wadsworth/Thomson Learning, Belmont.

Popkin, Richard, 1967, "Skepticism", in Paul Edwards (ed.), The Encyclopedia of Philosophy, Macmillan, New York, vol. 7, pp. 449-461.

Quinn, Philip L. and Kevin Meeker (eds.), 2000, The Philosophical Challenge of Religious Diversity, Oxford University Press, New York.

Rawls, John, 1993, Political Liberalism, Columbia University Press, New York.

Ribeiro, Brian, 2007, "Hume's Standard of Taste and the de gustibus Sceptic", British Journal of Aesthetics, vol. 47, no. 1, pp. 16-28.

Rorty, Richard, 1989, Contingency, Irony, and Solidarity, Cambridge University Press, Cambridge.

Sextus Empiricus, 2005, Against the Logicians [=Adversus Mathematicos 7-8], trans. Richard Bett, Cambridge University Press, Cambridge.

- 2000, Outlines of Scepticism [= Outlines of Pyrrhonism], trans. Julia Annas and Jonathan Barnes, Cambridge University Press, Cambridge. Shatz, David (ed.), 2002, Philosophy and Faith: A Philosophy of Religion Reader, McGraw-Hill, Boston.

Sunstein, Cass, 2003, Why Societies Need Dissent, Harvard University Press, Cambridge, Mass.

Wittgenstein, Ludwig, 1969, On Certainty, trans. Denis Paul and G.E.M. Anscombe, Basil Blackwell, Oxford.

—_, 1953, Philosophical Investigations, trans. G.E.M. Anscombe, Macmillan, New York.

-, 1922, Tractatus Logico-Philosophicus, trans. C.K. Ogden, Routledge and Kegan Paul, London.

Received: June 26, 2009; revised: September 16, 2010; accepted: December 1, 2010. 